RASĀYAN J. Chem.

Vol. 13 | No. 4 |2530-2537| October - December | 2020 ISSN: 0974-1496 | e-ISSN: 0976-0083 | CODEN: RJCABP

RJC http://www.rasayanjournal.com http://www.rasayanjournal.co.in

\title{
CHITOSAN-ZINC OXIDE NANOPARTICLE BASED HIGHLY SENSITIVE ELECTROCHEMICAL SENSOR FOR FORMALDEHYDE DETECTION
}

\author{
Saisa ${ }^{1,2}$, H. Agusnar ${ }^{3, *}$, Z. Alfian ${ }^{3}$ and I. Nainggolan ${ }^{3}$ \\ ${ }^{1}$ Doctoral Program, Department of Chemistry, Faculty of Mathematics and Natural Science, \\ Universitas Sumatera Utara, Medan 20155, Sumatera Utara, Indonesia \\ ${ }^{2}$ Department of Chemical Engineering, Faculty of Engineering, Universitas Serambi Mekkah, \\ Banda Aceh 23245, Aceh, Indonesia \\ ${ }^{3}$ Department of Chemistry, Faculty of Mathematics and Natural Science, Universitas Sumatera \\ Utara, Medan 20155, Sumatera Utara, Indonesia \\ *E-mail: harryagusnar@yahoo.com
}

\begin{abstract}
Chitosan nanoparticles (CS-NPs) have been widely used as sensor manufacturing materials, but until now the development of chitosan sensors using zinc oxide nanoparticles (ZnO-NPs) has not been carried out. This study aims to prepare several working electrodes based on chitosan nanoparticles on copper screen-printed electrode substrate $(\mathrm{Cu}-\mathrm{SPE})$ as a thin-film sensor $(\mathrm{CS}-\mathrm{ZnO})$ for formaldehyde detection. The sensitivity, selectivity, and responsiveness of each prepared working electrode were measured using the cyclic voltammetry $(\mathrm{CV})$ method. The best results for making working electrode (WE) for CS were obtained at $1.5 \% \mathrm{w} / \mathrm{v}$ concentration and the best CS$\mathrm{ZnO}$ mixture at $0.2 \% \mathrm{ZnO} \mathrm{w} / \mathrm{v}$ addition. The $\mathrm{CS}-\mathrm{ZnO}$ based sensor provided satisfying results. This can be evidenced by the ability of sensors are able to detect analytes at the lowest concentration, including LoD $=0.18$ $\mathrm{nM} / \mathrm{L}, \mathrm{LoQ}=0.59 \mathrm{nM} / \mathrm{L}$, sensitivity $1.54 \times 10^{-5} \mu \mathrm{A} / \mu \mathrm{M}$, and linear range $1-100 \times 10^{-5} \mu \mathrm{M} / \mathrm{L}$ with the correlation coefficient at $r^{2}=0.96$ for $n=5$. Due to the obtained result of the chitosan-based sensor, especially CS- $\mathrm{ZnO}$, this material can be categorized as a sensitive electrochemical sensor for formaldehyde detection purposes, and this sensor material has some advantages for further development, i.e. economics and efficiency.
\end{abstract}

Keywords: Chitosan NPs, Zinc Oxide NPs, Cyclic Voltammetry, Sensors, Formaldehyde

(C) RASĀYAN. All rights reserved

\section{INTRODUCTION}

Formaldehyde (HCHO) is intentionally added to various types of food products to prolong shelf life. Many studies about qualitative and quantitative to study formaldehyde have been conducted, especially for quantitative analysis, the study focus on using the HPLC, spectrophotometry, polarography and ion chromatography, gas chromatography (GC), fluorimetry, and mass spectrometer (MS) ${ }^{1,2,3}$. These methods are efficient due to expensive, complicated method, requires special handling, requires sample maintenance and takes a long time in the inspection process ${ }^{4}$. Within the technological development, an economical and environmentally technique has been developed, this technique based on the (bio) sensor application. The examination of formaldehyde for all previously developed sensors mostly done in liquid and gas form. The use of biopolymer as the sensor for detecting formaldehyde has been conducted using chitosan, with the presence of formaldehyde dehydrogenase, this sensor using gold as the electrode and resulted LoD of 3.15, and when it applied for detecting formaldehyde in seafood matrices, it has LoD of 5-16.8 ppm with $99 \%$ of linearity ${ }^{6}$. The other chitosan-based sensor also showed a satisfying result, i.e. PEI-chitosan electrodes ${ }^{7}, \mathrm{AgPd}$ chitosan-ionic liquid (AgPd/Ch-IL) nanoparticle alloys ${ }^{8}$. But that sensor above can be considered as not economics, the exploration of new chitosan-based sensor is still needed. The use of zinc oxide nanoparticles (ZnO-NPs) can be used as an alternative material to combine with chitosan. This is due to the several studies that have been conducted by using zinc oxide $(\mathrm{ZnO})$ itself or

Rasayan J. Chem., 13(4), 2530-2537(2020)

http://dx.doi.org/10.31788/ RJC.2020.1345786 
RASĀYAN J. Chem.

Vol. 13 | No. 4 |2530-2537| October - December | 2020

composited with other inorganic materials as electrodes ${ }^{9,10,11}$. The objective of this study was to prepare chitosan sensor-based that consisted of chitosan nanoparticle (CS-NPs), and chitosan-ZnO nanoparticle, the ability of chitosan-based sensor was determined using cyclic voltammetry method. Chitosan is a good semiconductor electrochemical as a thin-film matrix that able to increase high conductivity, whereas zinc oxide $(\mathrm{ZnO})$ nanoparticles have been declared as appropriate semiconductors used as a sensor because it has a unique advantage with high specific surface area, low toxicity, electrochemical activity, and high conductivity. The addition of $\mathrm{ZnO}$ to the chitosan matrix is assumed can increase the thermal stability and sensitivity of a thin-film sensor.

\section{Materials}

\section{EXPERIMENTAL}

Chitosan (medium molecular weight) nanoparticle, and zinc oxide nanoparticle ( 99\%), were purchased from Sigma Aldrich. Acetic Acid (10\%), formaldehyde (37\%), and copper substrates were provided from Merck.

\section{Making of copper electrode substrate (Cu-SPE)}

Cupper substrate $(\mathrm{Cu})$ was printed on the circuit board $\left(3 \times 1 \times 0.1 \mathrm{~cm}^{3}\right)$ with copper screen-printed electrode (SPE) coating process ${ }^{12}$. The sensor matrix was printed using a coating method on the surface of the sensing area on PCB substrate, and using a coating method on the surface of PCB was shown in Fig.-1 below:

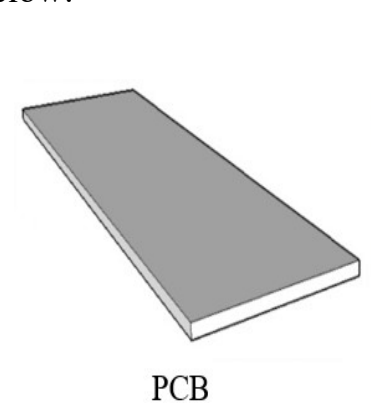

(Printed Circuit Board)

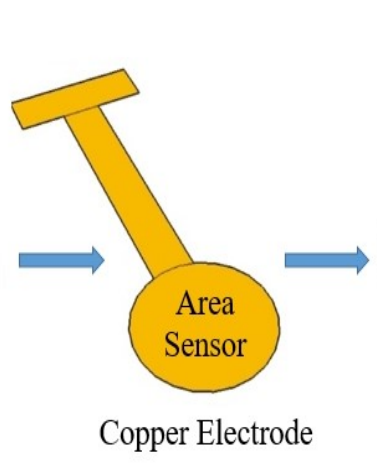

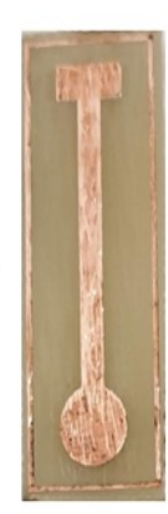

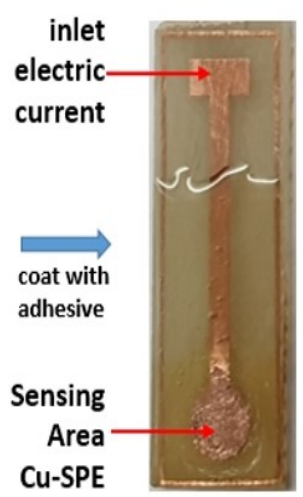

Cu-SPE

\section{Preparation of Chitosan Nanoparticle (CS-NPs)}

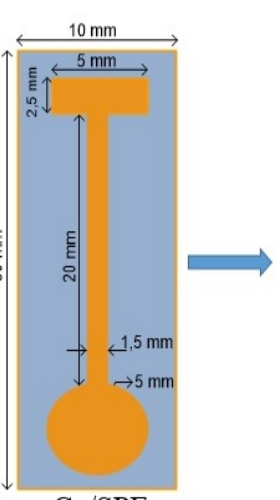

$\mathrm{Cu} / \mathrm{SPE}$

Chitosan nanoparticles $(1.0 \%$ and $1.5 \% \mathrm{w} / \mathrm{v})$ were prepared in $150 \mathrm{~mL}$ of acetic acid $2.0 \%$. The $\mathrm{pH}$ of the solution was adjusted to $4.5^{13}$. The dissolution process was carried out using a magnetic stirrer until the homogenous solution was obtained.

\section{Preparation of Zinc Oxide Nanoparticle (ZnO-NPs)}

Zinc oxide nanoparticles $(0.1,0.2$, and $0.3 \% \mathrm{w} / \mathrm{v})$ were prepared in $25 \mathrm{~mL}$ of acetic acid $2.0 \%$. The dissolution process was also carried out using a magnetic stirrer at room temperature until the homogenous solution was obtained.

\section{Mixing of Chitosan-Zinc Oxide Nanoparticle (CS-ZnO NPs)}

Thin-film matrices that have been prepared previously then carried out the mixing process according to variations in concentration chitosan $1.5 \% \mathrm{w} / \mathrm{v}$ was mixed with $\mathrm{ZnO}$ according to each concentration of $0.1 \%, 0.2 \%$, and $0.3 \% \mathrm{w} / \mathrm{v}$. The dissolution process was carried out using a magnetic stirrer with $100-300$ $\mathrm{rpm}$ rotation speed for 12 hours at room temperature until the solution was mixed homogeneously.

\section{Making of Phosphate Buffer Solution (PBS pH 7.0) and Formaldehyde}

The solution of phosphate buffer (PBS) $0.1 \mathrm{M}$ was prepared by mixing $2.89 \mathrm{~mL} \mathrm{Na}_{2} \mathrm{HPO}_{4}$ and $2.12 \mathrm{~mL}$ $\mathrm{NaH}_{2} \mathrm{PO}_{4}$ and diluted with distillate water in a $50 \mathrm{~mL}$ volumetric flask. The $\mathrm{pH}$ of the solution was adjusted using sodium hydroxide and phosphoric acid $\left(\mathrm{H}_{3} \mathrm{PO}_{4}\right)$ solution ${ }^{14,15}$. Formaldehyde solution $(0.01$, 
RASĀYAN J. Chem.

Vol. 13 | No. 4 |2530-2537| October - December | 2020

$0.05,0.1,0.5$, and $1.0 \% \mathrm{v} / \mathrm{v}$ ) was prepared from concentrated formaldehyde and diluted using the asprepared PBS solution.

\section{Electrochemical sensing Cyclic Voltammetry of CS-NPs, and CS-ZnO NPs}

The sensor area on $\mathrm{Cu}$-SPE used has a diameter of $5 \mathrm{~mm}$, in that area, several chitosan-based matrices were printed by placing $15 \mu \mathrm{l}$ of chitosan mixture solution, then heating on the hot plate until a thin film layer was obtained on the sensor area. The obtained chitosan-based sensor was then evaluated using cyclic voltammetry to see the sensitivity of the electrode as a sensor. The measurement was carried out using the as-prepared formaldehyde solution. The cyclic voltammetry system has three electrodes consisting of a working electrode (WE), reference electrode (RE), and counter electrode $(\mathrm{CE})^{16}$.

\section{Electrochemical methods of cyclic voltammetry}

\section{RESULTS AND DISCUSSION}

The electric potential measurement using cyclic voltammetry involves reduction and oxidation potential ${ }^{17,18}$. The detection of formaldehyde (formalin/HCHO) ${ }^{11}$ using cyclic voltammetry method in analyte solution involved three components of electrode cell, including working electrodes (WE) in this study was copper electrodes, the working electrode was chitosan-based matrices that coated on copper's surfaces $^{19,20}$. The working electrodes (WE) are a place where the oxidation reaction occurs, reduction of analytes, and these reactions are very dependent on the resulting potential value. Meanwhile, the counter electrode $(\mathrm{CE})$ in form of platinum $(\mathrm{Pt})$ has a function to flow current during the electrolysis process. The reference electrode (RE) in form of a saturated calomel electrode (SCE) containing $\mathrm{Hg}_{2} \mathrm{Cl}_{2}$ in a saturated solution of $\mathrm{KCl}$, as shown in Fig.-2 (a) an electrode whose potential value is known and always stable with time. Half of the reversible reactions occur on saturated calomel electrode (SCE) that the redox (reduction/oxidation) reversible reactions as below:

$$
\begin{aligned}
& 1 / 2 \mathrm{H}_{2}+1 / 2 \mathrm{Hg}_{2} \mathrm{Cl}_{2}(\mathrm{~s}) \leftarrow \rightarrow \mathrm{H}^{+}+\mathrm{Cl}^{-}+\mathrm{Hg} \\
& \mathrm{Hg}_{2} \mathrm{Cl}_{2}+2 \mathrm{e}^{-} \leftarrow \rightarrow 2 \mathrm{Hg}_{(l)}+2 \mathrm{Cl}^{-} \\
& 1 / 2 \mathrm{H}_{2} \leftarrow \rightarrow \mathrm{H}^{+}+\mathrm{e}^{-} \\
& (\mathrm{E}=0.241 \text { Volt })
\end{aligned}
$$

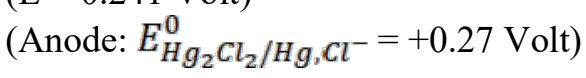

$$
\begin{aligned}
& \text { (Cathode) }
\end{aligned}
$$

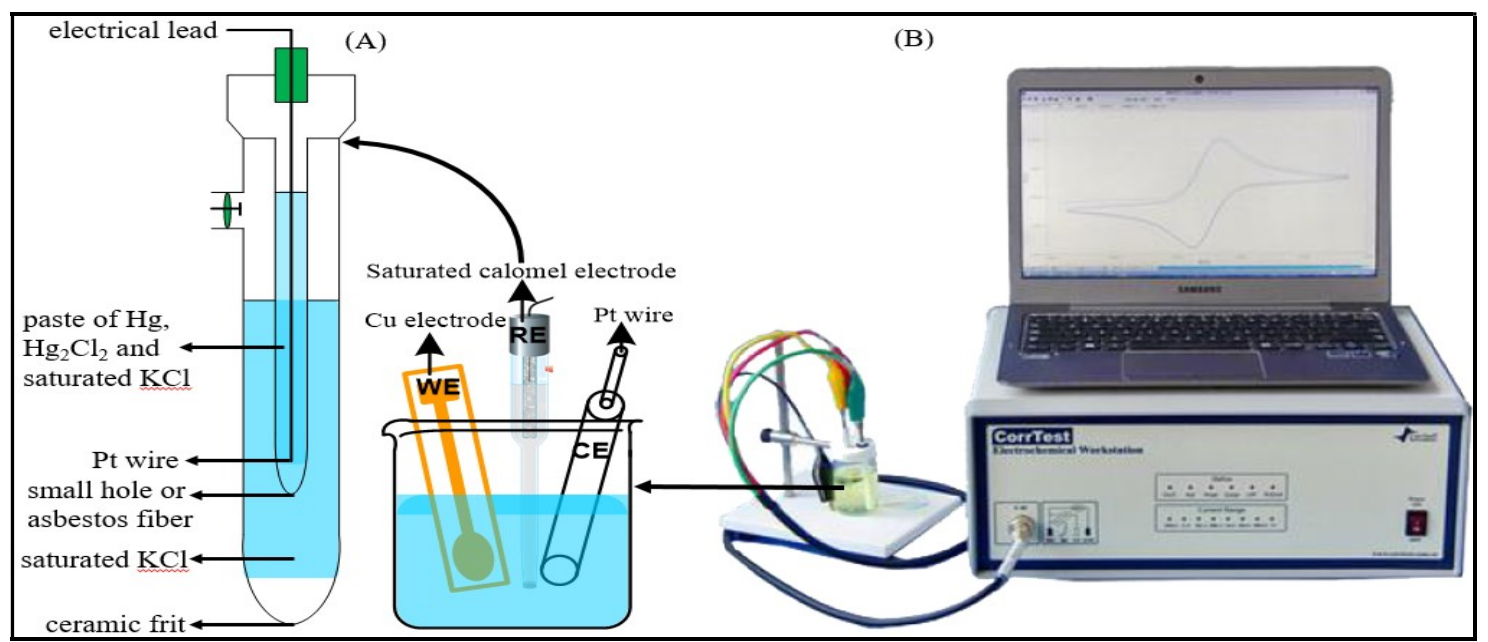

Fig.-2: Cyclic Voltammetry Process (A) Detail of Saturated Calomel Electrode, (B) Instrument of Cyclic Voltammetry

The working principle of cyclic voltammetry is shown in Fig.-2, the electric potential controlled by potensiostat is flowing into the working electrode (CS and CS-ZnO) and comparative electrode (SCE). The measurement was started by determining the electric field direction based on the electric potential value in the range of -1000 until $+1000 \mathrm{mV}$. The electrolyte solution is oxidized and continued by reduction, and conversely. ${ }^{21-23}$ 
RASĀYAN J. Chem.

Vol. 13 | No. 4 |2530-2537| October - December | 2020

\section{Copper Electrochemistry in Phosphate Buffer Solution}

Working electrode (WE) analysis was performed to evaluate the reactivity of copper electrodes in $0.1 \mathrm{M}$ phosphate buffer solution (PBS ${ }^{24,25}$. A copper electrode that reactive in PBS was used as subtractions in the coating of other working electrode matrices. The use of phosphate buffer and proper $\mathrm{pH}$ in the electrolysis process can increase electricity production on the performance of copper electrodes. Anode potential (oxidation) in buffer solution can help to minimize the changes of $\mathrm{pH}$. Meanwhile, the cathode potential (reduction) in the buffer solution can be maintained, as the impact on the $\mathrm{pH}$ of the solution will still stable ${ }^{26}$. The product of the oxidation and reduction of hydrogen phosphate anion $\left(\mathrm{HPO}_{4}{ }^{2-}\right)$ and dihydrogen phosphate $\left(\mathrm{H}_{2} \mathrm{PO}_{4}^{-}\right)$can be seen in the reaction below:

$$
\begin{aligned}
& \mathrm{HPO}_{4}^{2-}+\mathrm{OH}^{-}<===\left(\mathrm{PO}_{4}^{2-}\right)^{-}+\mathrm{H}_{2} \mathrm{O} \\
& 2\left(\mathrm{PO}_{4}^{2-}\right)^{-}<==>\mathrm{P}_{2} \mathrm{O}_{8}^{4-} \\
&\left(\mathrm{H}_{2} \mathrm{PO}_{4}\right)^{-}+\mathrm{OH}^{-}<==>\mathrm{H}_{3} \mathrm{PO}_{5}
\end{aligned}
$$
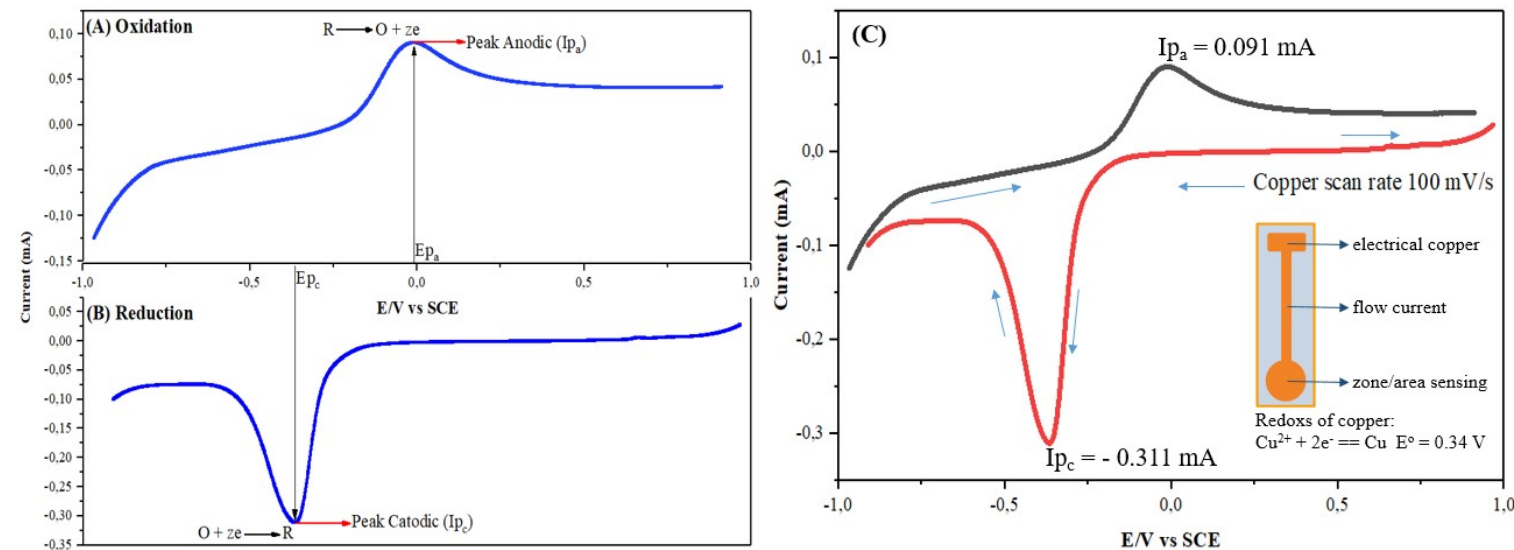

Fig.-3. Oxidation and Reduction Curves of Voltammetry Cell (A) Oxidation, (B) Reduction, (C) Standard Potential Copper $(\mathrm{Cu})$ Scan Rate $100 \mathrm{mV} / \mathrm{s}$

The potential standard of copper had been evaluated in PBS electrolyte solution to determine the potential value of cathode/anode peak (Ep) and value of cathode peak or anode peak current (Ip). Measurements had been made in the potential range of $-1,000 \mathrm{mV}$ to $1,000 \mathrm{mV}$. The measurement results were shown in Table-1 below:

Table-1: Electric potential and peak currents of copper electrodes in PBS

\begin{tabular}{c|c|c|c|c|c|c|c}
\hline $\mathrm{v}(\mathrm{mV} / \mathrm{s})$ & $\mathrm{Ep}_{\mathrm{a}}(\mathrm{mV})$ & $\mathrm{Ep}_{\mathrm{c}}(\mathrm{mV})$ & $\mathrm{Ip}_{\mathrm{a}}(\mathrm{mA})$ & $\mathrm{Ip}_{\mathrm{c}}(\mathrm{mA})$ & $\mathrm{Ip}_{\mathrm{c}} / \mathrm{Ip}_{\mathrm{a}}$ & $E^{o}(\mathrm{mV})$ & $\Delta \boldsymbol{E}_{\boldsymbol{p}}(\mathrm{mV})$ \\
\hline 100 & -15.034 & -366.82 & 0.091 & -0.311 & -3.418 & -190.927 & 351.786 \\
\hline
\end{tabular}

Figure-3(A) and (B) shows the oxidation and reduction on copper electrodes. The anodic peak indicated the occurrence of oxidation which was followed by the electron release during the process. This electron from the anodic process will be entrapped during the reduction at the cathode, the obtained peak is known as cathodic peak ${ }^{27}$. The current value of cathodic and anodic peak obtained from Fig.-3 (C), at a scan rate of $100 \mathrm{mV} / \mathrm{s}$ was $-0.311 \mathrm{~mA}$ and $0.091 \mathrm{~mA}$, respectively. Meanwhile, the highest potential value was produced by oxidation reaction at cathodic potential $(\mathrm{Epc}=-366.82 \mathrm{mV})$ and the lowest value at anodic potential was $-15,034 \mathrm{mV}$. Based on the cathodic peak value, it can be concluded as a good result due to the good reactivity, selectivity, and sensitivity of copper electrodes.

\section{Electrochemical Potential Properties of Chitosan Thin Film}

Chitosan (CS) is known as an amine-rich polymer and has an excellent ability to form thin films. A thinfilm of hydrated and dissolved chitosan in a salt solution can increase the conductivity ${ }^{28,29}$. The electrochemical potential measurement of chitosan using cyclic voltammetry in this study was carried out in a phosphate salt solution. Electrochemical potential measurements were performed to two concentration variations of chitosan. The results of the chitosan electrochemical voltammogram were shown in Fig.-4 below. 
RASĀYAN J. Chem.

Vol. 13 | No. 4 |2530-2537| October - December | 2020
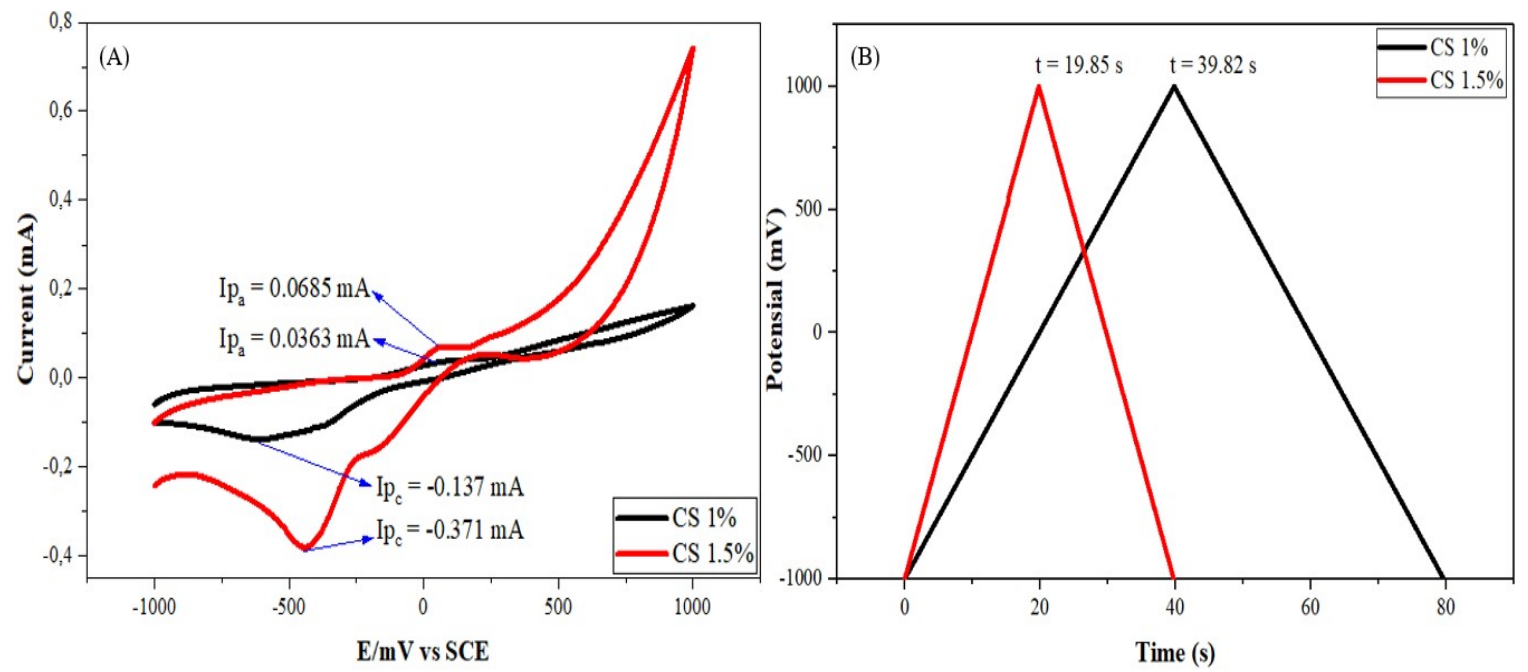

Fig.-4: Cyclic Voltammetry CS in PBS (A) Result Potential Cell Voltammetry CS 1\% and 1.5\% w/v, (B) Influence of Time on Potential Variations in CS Concentrations of $1 \%$ and $1.5 \% \mathrm{w} / \mathrm{v}$.

Figure-4(A) shows the highest electric current of cathodic/anodic peak was showed at the chitosan concentration of $1.5 \% \mathrm{w} / \mathrm{v}$. The difference in this concentration affects the time needed for analyzing, the highest the concentration of chitosan the time needed for performing analysis become faster. As shown in Fig.-4 (B), the analysis time for chitosan with $1.5 \% \mathrm{w} / \mathrm{v}$ of concentration only need $19.85 \mathrm{~s}$ (40 min), but for $1.0 \% \mathrm{w} / \mathrm{v}$ of chitosan needs more time, that was $39.82 \mathrm{~s}(80 \mathrm{~min})$.

\begin{tabular}{c|c|c|c|c|c|c|c}
\multicolumn{6}{c}{ Table-2: Measurement of Reduction/Oxidation Potential and Cathodic/Anodic Peak Currents of Chitosan } \\
\hline [C] CS $(\%)$ & $\mathrm{Ep}_{\mathrm{a}}(\mathrm{mV})$ & $\mathrm{Ep}_{\mathrm{c}}(\mathrm{mV})$ & $\mathrm{Ip}_{\mathrm{a}}(\mathrm{mA})$ & $\mathrm{Ip}_{\mathrm{c}}(\mathrm{mA})$ & $\mathrm{Ip}_{\mathrm{c}} / \mathrm{Ip}_{\mathrm{a}}$ & $E^{o}(\mathrm{mV})$ & $\Delta \boldsymbol{E}_{\boldsymbol{p}}(\mathrm{mV})$ \\
\hline 1 & 64.462 & -594.09 & 0.0363 & -0.137 & -3.774 & -264.81 & 658.552 \\
1.5 & 55.689 & -472.71 & 0.0685 & -0.371 & -5.416 & -208.51 & 528.339 \\
\hline
\end{tabular}

Table-2 shows that both concentrations of chitosan produce a sensitive and selective result, especially in the current of the cathodic and anodic peaks. Based on the values of $\mathrm{E}$ and I of these results, chitosan with a concentration of $1.5 \% \mathrm{w} / \mathrm{v}$ was chosen for further analysis.

\section{Electrochemical Potential of Chitosan-ZnO Thin Film}

The addition of $\mathrm{ZnO}$ in the chitosan matrix can be used to improve the chemical stability of the sensor. Zinc oxide was chosen due to its nano-sized and other advantages, i.e. high surface area, low toxicity, electrochemical potent, and high conductivity. ${ }^{30,31}$ The result of cyclic voltammetry analysis was shown in Fig.-5 and summarized in Table-3. Three different concentrations of $\mathrm{ZnO}$ that were added into a chitosan solution with $1.5 \% \mathrm{w} / \mathrm{v}$ of concentration showed a very reactive result. The best current of the cathodic peak was obtained at $\mathrm{ZnO}$ of $0.2 \% \mathrm{w} / \mathrm{v}$.

The reduction potential of the chitosan-based sensor at the addition of $0.2 \% \mathrm{w} / \mathrm{v}$ has a greater value than 0.1 and $0.3 \% \mathrm{w} / \mathrm{v}$. The current of the cathodic and anodic peaks also showed a similar result at the addition of $\mathrm{ZnO} 0.2 \% \mathrm{w} / \mathrm{v}$. Based on these results, the addition of $\mathrm{ZnO} 0.2 \% \mathrm{w} / \mathrm{v}$ into the chitosan matrix can be used for further analysis.

Table-3: Measurement of Potential and Peak Currents for Reduction/Oxidation of CS Doped ZnO

\begin{tabular}{|c|c|c|c|c|c|c|c|}
\hline$[\mathrm{C}] \mathrm{ZnO}(\%)$ & $\mathrm{Ep}_{\mathrm{a}}(\mathrm{mV})$ & $\mathrm{Ep}_{\mathrm{c}}(\mathrm{mV})$ & $\operatorname{Ip} p_{a}(m A)$ & $\mathrm{Ip}_{\mathrm{c}}(\mathrm{mA})$ & $\mathrm{Ip}_{\mathrm{c}} / \mathrm{Ip} \mathrm{p}_{\mathrm{a}}$ & $E^{o}(\mathrm{mV})$ & $\Delta \boldsymbol{E}_{\boldsymbol{p}}(\mathrm{mV})$ \\
\hline 0.1 & 11.59 & -444.71 & 0.0275 & -0.1726 & -6.2764 & -216.56 & 456.30 \\
\hline 0.2 & 116.57 & -393.06 & 0.1232 & -0.3151 & -2.5576 & -138.25 & 509.63 \\
\hline 0.3 & 20.37 & -353.01 & 0.0201 & -0.0501 & -2.4925 & -166.32 & 373.38 \\
\hline
\end{tabular}


RASĀYAN J. Chem.

Vol. 13 | No. 4 |2530-2537| October - December | 2020

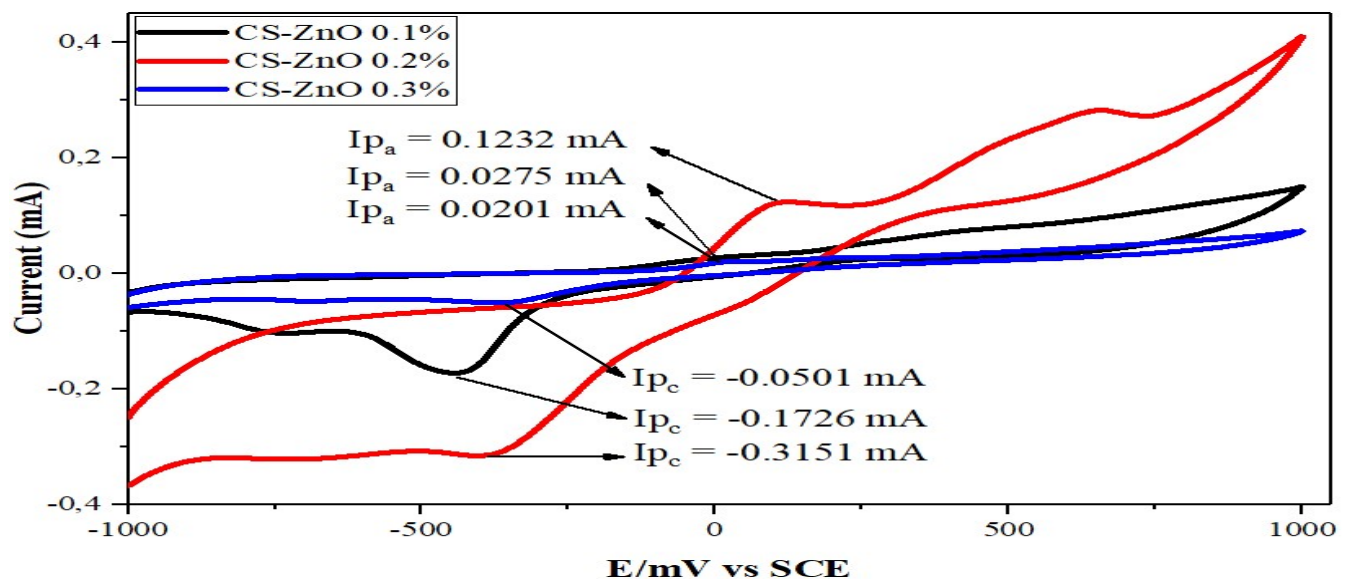

Fig.-5: Cyclic Voltammogram CS Doped ZnO at Variation of Concentration $0.1 \%, 0.2 \%$, and $0.3 \% \mathrm{w} / \mathrm{v}$

\section{Sensitivity, Linear Range, LoD, and LoQ CS-ZnO Thin-Film Formaldehyde Sensors}

The sensitivity, linear range, $\mathrm{LoD}$ and $\mathrm{LoQ}$ value of CS-ZnO thin-film was determined by the cyclic voltammetry method for detecting formaldehyde. These parameters are mandatory to determine for achieving a good material for sensor application ${ }^{5,32}$.
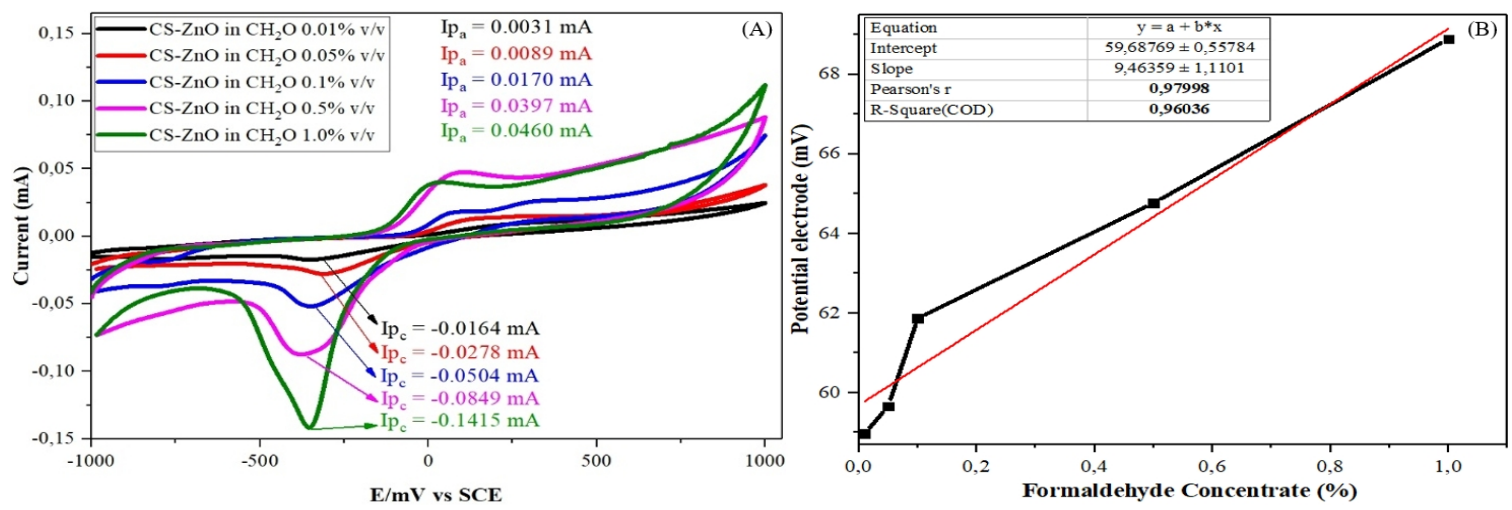

Fig.-6: CV Curve Voltammogram Electrode of CS-ZnO Formaldehyde Sensors (A) Curve Voltammogram on Variations of Formaldehyde Concentration, (B) Linear Range CS-ZnO Formaldehyde Sensors

The detection of formaldehyde using chitosan-ZnO thin-film was shown in Fig.-6. The measurement was performed using a standard solution of formaldehyde, i.e. $1,5,10,50,100 \times 10^{-5} \mu \mathrm{M}$ at the scan rate of 100 $\mathrm{mV} / \mathrm{s}$. Based on the results in Fig.-6 (A), thin-film CS-ZnO showed a good responsibility for formaldehyde detection. The linear correlation was obtained between the formaldehyde concentration and the electrode response produced, especially the current peak and electric potential value.

The chitosan- $\mathrm{ZnO}$ can be used as a working electrode due to it able to give a response at the low concentration of an analyte, about $1.54 \times 10^{-5} \mu \mathrm{A} / \mu \mathrm{M}$. Afterward, the linear region for detecting CS-ZnO working electrodes observed based on the influence of formaldehyde concentration on the electrode potential as shown in Fig.-6 (B), from the measurement, the linear correlation coefficient value was obtained about $\mathrm{r}^{2}=0.96$ for $\mathrm{n}=5$ with a linear range limit is $1-100 \times 10^{-5} \mu \mathrm{M} / \mathrm{L}^{36}$.

Table-4: Comparison of Different Modified Electrodes for Detecting Formaldehyde

\begin{tabular}{|c|c|c|c|c|c|c|}
\hline Electrode & Method & $\begin{array}{l}\text { Sensitivity } \\
(\mu \mathrm{A} / \mu \mathrm{M})\end{array}$ & Linear Range $\left(\mu \mathrm{M} \cdot \mathrm{L}^{-1}\right)$ & LOD $\left(\mathrm{nM} \cdot \mathrm{L}^{-1}\right)$ & $\begin{array}{c}\text { LOQ } \\
\left(\mathrm{nM} \cdot \mathrm{L}^{-1}\right)\end{array}$ & Ref. \\
\hline Nikel-GCE & Potentiometric & $22.7 \mu \mathrm{A} / \mathrm{mM}$ & $1 \times 10^{-5}-1 \times 10^{-3} \mathrm{M}$ & $1.1 \times 10^{-5} \mathrm{M}$ & - & 33 \\
\hline $\mathrm{C} / \mathrm{Co}_{2} \mathrm{P} / \mathrm{Pd}$ & Amperometric & $617 \mathrm{nA} / \mathrm{ppm}$ & $1-10 \mathrm{ppm}$ & $0.25 \mathrm{ppm}$ & - & 34 \\
\hline $\mathrm{Ni} / \mathrm{P}-\mathrm{CPE}$ & Amperometric & 43.07 & $0.02-11.5 \mathrm{mM}$ & $5.8 \mu \mathrm{M}$ & - & 35 \\
\hline
\end{tabular}


RASĀYAN J. Chem.

Vol. 13 | No. 4 |2530-2537| October - December | 2020

\begin{tabular}{c|c|c|c|c|c|c}
\hline $\mathrm{ZnO}$ nanosheet & Amperometric & $2.7 \times 10^{-4}$ & $1 \times 10^{-8}-1 \times 10^{-3}$ & 210 & - & 11 \\
\hline $\mathrm{CS}-\mathrm{ZnO}$ & Voltammetry & $1.54 \times 10^{-5}$ & $1-100 \times 10^{-5}$ & 0.18 & 0.59 & This work \\
\hline
\end{tabular}

The LoD and LoQ value from this measurement was about 0.18 and $0.59 \mathrm{nM} / \mathrm{L}$, respectively ${ }^{37,38}$. The working electrode of chitosan nanoparticles (CS-NPs) doped with zinc oxide nanoparticles (ZnO-NPs) was able to show good selectivity, sensitivity and responsiveness as sensors detecting formaldehyde in electrolyte solutions.

\section{CONCLUSION}

In connection with the results of research and measurements that have been carried out following the results obtained in the electrochemical process of cyclic voltammetry for the manufacture of thin-film sensors as work electrodes made from chitosan nanoparticles (CS-NPs) as a basic matrix combined with the addition of zinc oxide $(\mathrm{ZnO})$ has been successfully carried out in this study. Initial sensor performance tests were performed on CS-NPs, and CS-ZnO NPs, matrices in a phosphate buffer solution $\mathrm{pH} 7.0$ electrolyte solution, where each electrode giving the best results for CS matrix was obtained at a concentration of $1.5 \% \mathrm{w} / \mathrm{v}, \mathrm{CS}-\mathrm{ZnO} 0.2 \% \mathrm{w} / \mathrm{v}$. Analysis of selectivity, sensitivity, linear range, the limit of detection, and limit of quantification for $\mathrm{CS}-\mathrm{ZnO}$ thin-film sensors that have been carried out for detection of formaldehyde ( $\mathrm{HCHO})$ in various variations of analyte concentrations. This provides excellent results as evidenced by the ability of CS-thin film sensors $\mathrm{ZnO}$ can detect the analyte at the lowest concentration with $\mathrm{LoD}$ value of $0.18 \mathrm{nM} / \mathrm{L}$ and $\mathrm{LoQ}=0.59 \mathrm{nM} / \mathrm{L}$. The cyclic voltammetry method is very appropriate to be used in making CS-ZnO thin-film sensors because it can provide a good response as a thin-film sensor in the detection of formaldehyde and also the process of making sensor substrate is very economical and efficient with low preparation costs.

\section{ACKNOWLEDGEMENT}

The author thanks to the Institution of Education Fund Management (LPDP) for the doctoral scholarship and research grant. Thanks also are given to the thesis supervisor (Universitas Sumatera Utara), and Universitas Serambi Mekkah, Banda Aceh as the author's institution.

\section{REFERENCES}

1. Y.L. Li, J. Liu, and W.S. Guan, in 3rd International Conference on Bioinformatics and Biomedical Engineering, 10777577, 1(2009), DOI:10.1109/ICBBE.2009.5162632

2. J.A. Jendral, Y.B. Monakhova, and D.W. Lachenmeier, International Journal of Analytical Chemistry, 797604, 11(2011), DOI: 10.1155/2011/797604

3. A. Gholami, A. Mohsenikia, and S. Masoum, Journal of Analytical Methods in Chemistry, 1720530, 8(2016), DOI: 10.1155/2016/1720530

4. D. Kukkar, K. Vellingiri, R. Kaur, S.K. Bhardwaj, A. Deep, and K.-H. Kim, Nano Research, 12, 225(2019), DOI: $10.1007 / \mathrm{s} 12274-018-2207-5$

5. K. Tsuchiya, H. Furusawa, A. Nomura, H. Matsui, M. Nihei, and S. Tokito, Technologies, 7(3), 48(2019), DOI: 10.3390/technologies7030048

6. K. Rovina, J.M. Vonnie, S.N. Shaeera, S.X. Yi, and N.F.A. Halid, Sensing and Bio-Sensing Research, 27, 100310(2019), DOI:10.1016/j.sbsr.2019.100310

7. N. Wang, X. Wang, Y. Jia, X. Li, J. Yu, and B. Ding, Carbohydrate Polymers, 108, 192(2014), DOI: $10.1016 /$ j.carbpol.2014.02.088

8. Q. Wang, J. Zheng, and H. Zhang, Journal of Electroanalytical Chemistry, 674, 1(2012), DOI: 10.1016/j.jelechem.2012.02.009

9. H.H.M. Yusof, M.H. Jali, M.A.M. Johari, K. Dimyati, S.W. Harun, M. Khasanah, and M. Yasin, IEEE Photonics Journal, 11(1), 1(2019), DOI:10.1109/JPHOT.2019.2895024

10. W. Guo, B. Zhao, Q. Zhou, Y. He, Z. Wang, and N. Radacsi, ACS Omega, 4(6), 10252(2019), DOI: 10.1021/acsomega.9b00734

11. E.-B. Kim and H.-K. Seo, Materials, 12(2), 250(2019), DOI: 10.3390/ma12020250

12. F.T.C. Moreira, M.J.M.S. Ferreira, J.R.T. Puga, and M.G.F. Sales, Sensors and Actuators B: Chemical, 223, 927(2016), DOI:10.1016/j.snb.2015.09.157 
RASĀYAN J. Chem.

Vol. 13 | No. 4 |2530-2537| October - December | 2020

13. S.E. Cahyaningrum, N. Herdyastuti, A. Firdausa, and D. Yanrita, Rasayan Journal of Chemistry, 10(3), 959(2017), DOI: 10.7324/RJC.2017.1031635

14. S. R. Moraes, D. Huerta-Vilca, and A. J. Motheo, European Polymer Journal, 40(9), 2033(2004), DOI:10.1016/j.eurpolymj.2004.05.016

15. J. Sambrook, E. F. Fritsch, and T. Maniatis, Molecular cloning: a laboratory manual, Cold Spring Harbor Laboratory, (1989).

16. R.B. Kohakade, E.S. Kumar, R.W. Gaikwad, S. Raghu, and R.A. Kalaivani, Rasayan Journal of Chemistry, 10(4), 1151(2017), DOI:10.7324/RJC.2017.1041881

17. R.J. Forster and L.R. Cumba, in Encycl. Anal. Sci. (Third Ed., edited by P. Worsfold, C. Poole, A. Townshend, and M.B.T.-E. of A.S. (Third E. Miró (Academic Press, Oxford, 2019), pp. 197-208.

18. V.R.N. Banu, V.R. Babu, C. Kayalvizhi, and K. Saravanan, Rasayan Journal of Chemistry, 12(4), 1881(2019), DOI:10.31788/RJC.2019.1245339

19. A. Kurniawan, F. Kurniawan, F. Gunawan, S.-H. Chou, and M.-J. Wang, Electrochimica Acta, 293, 318(2019), DOI:10.1016/j.electacta.2018.08.140

20. J. Liang, Y. Zheng, and Z. Liu, Sensors and Actuators B: Chemical, 232, 336(2016), DOI: 10.1016/j.snb.2016.03.145

21. M. Rudolph, D.P. Reddy, and S.W. Feldberg, Analytical Chemistry, 66(10), 589A(1994), DOI: 10.1021/ac00082a725

22. H.M. Elqudaby, H.A.M. Hendawy, E.R. Souaya, G.G. Mohamed, and G.M.G. Eldin, International Journal of Electrochemistry, 8621234, 1(2016), DOI:10.1155/2016/8621234

23. S.H.S. Dananjaya, R.S. Kumar, M. Yang, C. Nikapitiya, J. Lee, and M. De Zoysa, International Journal of Biological Macromolecules, 108, 1281(2018), DOI:10.1016/j.ijbiomac.2017.11.046

24. O.K. Lebedeva, V.S. Snytko, I.I. Kuznetsova, D.Y. Kultin, A.N. Zakharov, and L.M. Kustov, Russian Journal of Physical Chemistry A, 93, 168(2019), DOI:10.1134/S0036024419010175

25. H.-Y. Liu, L.-L. Zhu, Z.-H. Huang, Y.-B. Qiu, H.-X. Xu, J.-J. Wen, W.-W. Xiong, L.-H. LI, and C.C. Gu, Chinese Journal of Analytical Chemistry, 47(9), e19113(2019), DOI:10.1016/S18722040(19)61183-7

26. D. Sari, L. Suyati, and D.S. Widodo, Journal of Scientific and Applied Chemistry, 19(3), 107(2016).

27. P.H. Rieger, in Electrochemistry, edited by P.H. Rieger (Springer Netherlands, Dordrecht, 1994), pp. $1-58$.

28. S.B. da Silva, G.L. Batista, and C.K. Santin, Chitin and Chitosan, 461(2019).

29. I. Nainggolan, D. Shantini, T.I. Nasution, and M.N. Derman, Advances in Materials Science and Engineering, 702815, 8(2015), DOI:10.1155/2015/702815

30. X. Fang, Y. Bando, U.K. Gautam, T. Zhai, H. Zeng, X. Xu, M. Liao, and D. Golberg, Critical Reviews in Solid State and Materials Sciences, 34(3-4), 190(2009), DOI: 10.1080/10408430903245393

31. Y. Tak, S.J. Hong, J.S. Lee, and K. Yong, Journal of Materials Chemistry, 19(33), 5945(2009), DOI:10.1039/b904993b

32. M. K. L. Coelho, D. Nunes da Silva, and A. César Pereira, Chemosensors, 7(3), 32(2019), DOI: 10.3390/chemosensors 7030032

33. D. Trivedi, J. Crosse, J. Tanti, A.J. Cass, and K.E. Toghill, Sensors and Actuators B: Chemical, 270, 298(2018), DOI:10.1016/j.snb.2018.05.035

34. H. Wang, Y. Chi, X. Gao, S. Lv, X. Chu, C. Wang, L. Zhou, and X. Yang, Journal of Chemistry, 2346895, 9(2017), DOI: $10.1155 / 2017 / 2346895$

35. S.N. Azizi, S. Ghasemi, and F. Amiripour, Sensors and Actuators B: Chemical, 227, 1(2016), DOI: 10.1016/j.snb.2015.11.142

36. C. Engin, S. Yilmaz, G. Saglikoglu, S. Yagmur, and M. Sadıkoğlu, International Journal of Electrochemical Science, 10, 1916(2015).

37. D.A. Armbruster and T. Pry, The Clinical Biochemist, 29 Suppl 1, S49(2008).

38. S.K. Vashist and J.H.T. Luong, in Handb. Immunoass. Technol, edited by S.K. Vashist and J.H.T.B.T.-H. of I.T. Luong (Academic Press, 2018), pp. 81-95.

[RJC-5786/2020] 